\title{
PENINGKATAN HASIL BELAJAR IPA MELALUI PENERAPAN MODEL PEMBELAJARAN COOPERATIVE TIPE STUDENT TEAMS ACHIEVEMENT DIVISION (STAD) PADA SISWA KELAS V SEKOLAH DASAR Oleh: \\ Dicky Prastya ${ }^{1}$ \\ STKIP PGRI METRO
}

\begin{abstract}
This research aims to improve the student learning output in science subject by utilizing cooperative model of student teams achievement division (STAD) type at the fifth class $B$ of elementary school 1 Sidokerto district Bumiratu Nuban. This study was a classroom action research. The results showed that the type cooperative learning model student teams achievement division (STAD) can improve students' learning activities, judging from the average percentage of student learning activities in the first cycle of $77 \%$ and $85.5 \%$ the second cycle. The implementation of cooperative learning model type of student teams' achievement division (STAD) may also increase the thoroughness of learning outcomes IPA. The percentage of students who complete the first cycle is $62.5 \%$ and the second cycle is $90.63 \%$ and an increase in the average score of $N$-Gain.
\end{abstract}

Keywords: Learning Achievement, Cooperative STAD

\begin{abstract}
Abstrak: Penelitian ini bertujuan untuk meningkatan hasil belajar IPA pada siswa kelas VB SDN1 Sidokerto Kecamatan Bumiratu Nuban dengan menggunakan model pembelajaran cooperative tipe student teams achievement division (STAD).Penelitian ini termasuk dalam Penelitian Tindakan Kelas. Hasil penelitian menunjukkan bahwa model pembelajaran cooperative tipe student teams achievement division (STAD) dapat meningkatkan aktivitas belajar siswa, dilihat dari rata-rata persentase aktivitas belajar siswa pada siklus I sebesar 77\% dan siklus II 85,5\%. Penerapan model pembelajaran cooperative tipe student teams achievement division (STAD)juga dapat meningkatkan ketuntasan hasil belajar IPA. Persentase siswa yang tuntaspada siklus I sebesar 62,5\% dan siklus II sebesar 90,63\% dan terjadi peningkatan pada skor rata-rata N-Gain.
\end{abstract}

Kata Kunci: Hasil Belajar, Cooperative tipe student teams achievement division (STAD).

\section{PENDAHULUAN}

Ilmu Pengetahuan Alam (IPA) merupakan hasil kegiatan manusia berupa pengetahuan, gagasan, dan konsep yang terorganisasi tentang alam sekitarnya yang diperoleh dari pengalaman melalui serangkaian proses ilmiah seperti penyelidikan, penyusunan dan pengujian gagasan. Dalam pembelajaran IPA, siswa diarahkan untuk berbuat sehingga memperoleh pemahaman yang lebih mendalam tentang alam sekitar. Dengan mempelajari IPA siswa akan menambah pengetahuan melalui proses pengamatan, pengalaman, penyusunan gagasan yang dapat diaplikasikan dalam kehidupan sehari-hari, kehidupan bermasyarakat.

Salah satu masalah pokok dalam pembelajaran di kelas VB SD Negeri 1
Sidokerto yaitu rendahnya daya serap siswa. Kenyataan itu dapat dilihat dari observasi yang peneliti laksanakan, hal ini nampak dari rendahnya hasil belajar yang diperoleh siswa. Selain itu, guru belum menggunakan model pembelajaran yang inovatif, kreatif, dan menyenangkan secara maksimal. Proses belajar masih didominasi oleh guru dengan menjelaskan materi melalui ceramah dan pemberian tugas. Siswa hanya mendengarkan guru sehingga siswa merasa bosan dan tidak berperan aktif dalam pembelajaran. Mata pelajaran IPA pun masih sering dianggap sebagai mata pelajaran yang menuntut kemampuan menghafal. Berbagai permasalahan dalam pembelajaran di kelas tentu akan berpengaruh pada hasil belajar yang diperoleh siswa.

\footnotetext{
${ }^{1}$ STKIP PGRI METRO, Email: dickyprastya47@gmail.com
} 
Penggunaan model pembelajaranyang inovatif, kreatif, dan menyenangkan, serta pelaksanaan evaluasi hasil belajar merupakan aspek-aspek yang mempengaruhi keberhasilan belajar. Proses pembelajaran yang seharusnya yaitu proses pembelajaran yang menciptakan hubungan timbal balik antara guru dengan siswa maupun siswa dengan siswa. Dengan demikian siswa akan berperan aktif dalam pembelajaran, terutama melibatkan aktivitas mental siswa dalam situasi belajarnya.

Berdasarkan hasil prasurvei, wawancara dengan guru bidang studi IPA kelas VB SD Negeri 1 Sidokerto kondisi kelas saat kegiatan belajar mengajar IPA masih sering pasif. Sangat sulit terjadinya interaksi aktif baik antara siswa dengan siswa maupun siswa dengan guru. Hasil belajar pun masih cenderung rendah. Setelah peneliti cermati ternyata keadaan tersebut tidak lepas dari penggunaan model pembelajaran yang digunakan. Selama pembelajaran IPA proses pembelajaran masih didominasi oleh guru dengan menjelaskan materi melalui ceramah dan pemberian tugas, siswa hanya mendengarkan. Rendahnya hasil belajar siswa dapat dilihat dari nilai uji blok. Masih banyak siswa yang belum mencapai Kriteria KetuntasanMinimal (KKM) yang telah ditetapkan di SD Negeri 1 Sidokerto yaitu 60. Hal tersebut dapat dilihat pada tabel berikut.

Tabel 1. Daftar nilai uji blok IPA siswa

\begin{tabular}{|l|l|l|l|}
\hline No & Nilai & $\begin{array}{l}\text { Jumlah } \\
\text { Siswa }\end{array}$ & Presentase \\
\hline 1 & $\geq 60$ & 18 & $56,25 \%$ \\
\hline 2 & $<60$ & 14 & $43,75 \%$ \\
\hline \multicolumn{2}{|l|}{ Jumlah } & 32 & $100 \%$ \\
\hline
\end{tabular}

Menanggapi

permasalahan tersebut,beberapa permasalahan yang dapat diidentifikasi yaitu; rendahnya hasil belajar yang diperoleh siswa kelas VB SD Negeri 1 Sidokerto dalam mata pelajaran Ilmu Pengetahuan Alam (IPA) dengan ditandai 14 siswa tidak tuntas, sudah menggunakan berbagai metode pembelajaran seperti ceramahdan pemberian tugas akan tetapi hasil belajar masih rendah, proses pembelajaran belum menggunakan model pembelajaran yang inovatif, kreatif, dan menyenangkan, dan masih banyak siswa yang kurang memperhatikan serta malas bertanya tentang materi pelajaran yang belum dipahami.

Selanjutnya, permasalahan yang muncul adalah bagaimana guru dapat menciptakan proses pembelajaran yang melibatkan peran siswa secara aktif. Proses pembelajaranjuga diharapkan dapat meningkatkan pemahaman siswa pada materi, sehingga hasil belajar pun meningkat. Untuk itu penulis memberikan solusi yaitu menggunakan model pembelajaran cooperative tipe student teams achievement division (STAD). Model pembelajaran cooperative tipe student teams achievement division (STAD) adalah salah satu model pembelajaran yang dapat meningkatkan hasil belajar. Sebagaimana dikemukakan oleh Isjoni, dalam bukunya cooperative learning, bahwa pada dasarnya model cooperative learning dikembangkan untuk mencapai tiga tujuan pembelajaran yaitu meningkatkan hasil belajar akademik, penerimaan terhadap perbedaan individu, dan pengembangan ketrampilan sosial.

Berdasarkan permasalahan di atas pembelajaran dengan menggunakan model cooperative tipe student teams achievement division (STAD) dipandang cocok digunakan sebagai salah satu alternatif dalam pembelajaran Ilmu Pengetahuan Alam (IPA) untuk mencapai hasil belajar yang diharapkan. Hal ini sesuai dengan pernyataan bahwa model cooperative tipe student teams achievement division (STAD) merupakan salah satu tipe yang menekankan adanya aktivitas dan interaksi diantara siswa untuk saling memotivasi dan saling membantu dalam menguasai materi pelajaran guna mencapai prestasi yang maksimal. Sehingga dengan adanya aktivitas dan interaksi antar siswa yang 
aktif akan berdampak pada hasil belajar yang dicapai siswa.

Adapun kelebihan model cooperative tipe student teams achievement division (STAD) menurut Roestiyah (2001: 17), yaitu: dapat memberikan kesempatan kepada siswa untuk menggunakan keterampilan bertanya dan membahas suatu masalah, dapat memberikan kesempatan kepada siswa untuk lebih intensif mengadakan penyelidikan mengenai suatu masalah, dapat mengembangkan bakat kepemimpinan dan mengajarkan keterampilan berdiskusi, dapat memungkinkan guru untuk lebih memperhatikan siswa sebagai individu dan kebutuhan belajarnya, para siswa lebih aktif bergabung dalam pelajaran mereka dan mereka lebih aktif dalam diskusi, dan dapat memberikan kesempatan kepada siswa untuk mengembangkan rasa menghargai, menghormati pribadi temannya, dan menghargai pendapat orang lain.

Pembelajaran cooperative dengan istilah lain yaitu pembelajaran gotongroyong memberikan kesempatan kepada siswa untuk bekerja sama. Menurut Anita Lie "Pembelajaran cooperative dengan istilah pembelajaran gotong-royong, yaitu sistem pembelajaran yang memberi kesempatan kepada peserta didik untuk bekerjasama dengan siswa lain dalam tugas-tugas yang terstruktur".

Pada kelas cooperative siswa dibagi menjadi beberapa kelompok dengan memperhatikan perbedaan jenis kelamin, kemampuan akademik, suku, agama. Hal tersebut sesuai dengan pendapat Slavin dalam Triyanto bahwa pada cooperative tipe student teams achievement division (STAD) bahwa siswa ditempatkan dalam tim belajar beranggotakan 4-5 orang yang merupakan campuran menurut tingkat prestasi, jenis kelamin, dan suku.

Pembelajaran pada model pembelajaran cooperative tipe student teams achievement division (STAD), guru lebih dahulu menjelaskan atau menyajikan materi, kemudian anggota tim mempelajari materi tersebut dalam kelompoknya. Siswa dilengkapi dengan lembar kerja dan juga diberi latihan, tugas-tugasnya harus dikuasai oleh setiap anggota kelompok. Setiap anggota kelompok harus memberikan skor terbaik kepada kelompoknya dengan menunjukkan peningkatan penampilan dibanding dengan sebelumnya. Kelompok yang tanpa memiliki anggota-anggota yang meningkat nilainya dan menghasilkan skor yang tidak sempurna tidak akan menang atau tidak mendapat penghargaan berupa hadiah atau lainnya. Pada akhirnya guru memberikan kuis yang dikerjakan siswa secara individu. Pembelajaran dengan model cooperative tipe student teams achievement division (STAD) memberikan penghargaan kepada kelompok yang mendapat predikat tim super. Penghargaan atas keberhasilan kelompok dilakukan oleh guru dengan tahapan-tahapan sebagai berikut: menghitung skor individu, menghitung skor kelompok, dan pemberian hadiah dan pengakuan skor kelompok.

Pada penelitian ini hasil belajar yang dimaksud adalah hasil belajar siswa pada mata pelajaran ilmu pengetahuan alam (IPA) yang ditunjukkan dengan nilai dari pretest dan posttest setiap akhir siklus setelah mengikuti proses pembelajaran dengan model pembelajaran cooperative tipe student teams achievement division (STAD).

Untuk membatasi penelitian ini agar tidak terlalu luas maka peneliti membatasi penelitian ini berdasarkan identifikasi masalah yang telah dikemukakan sebelumnya yaitu rendahnya hasil belajar siswa yang diperoleh siswa kelas VB SD Negeri 1 Sidokerto dalam mata pelajaran Ilmu Pengetahuan Alam (IPA).

Materi yang dipilih pada penelitian ini yaitu air dan peristiwa alam yang terjadi di Indonesia. Pemilihan materi ini disebabkan penyesuaian waktu dengan jadwal yang disusun oleh wali kelas, sehingga peneliti tidak mengganggu jalannya proses pembelajaran.

Tujuan dari penelitian tindakan kelas ini adalahuntuk meningkatan hasil 
belajar IPA pada siswa kelas VB SD Negeri 1 Sidokerto Kecamatan Bumiratu Nuban dengan menggunakan model pembelajaran cooperative tipe student teams achievement division (STAD).

Hasil penelitian tindakan kelas ini diharapkan dapat memberikan manfaat antara lain: bagi siswa dapat meningkatkan pemahaman konsep Ilmu Pengetahuan Alam sehingga dapat meningkatkan aktivitas dan hasil belajar siswa, bagi guru dapat memperluas pengetahuan mengenai model-model pembelajaran Ilmu Pengetahuan Alam sehingga dapat digunakan untuk meningkatkan dan mengembangkan kemampuan profesional guru dalam melaksanakan pembelajaran di kelas, dan bagi sekolah dapat memberikan sumbangan pemikiran yang berguna dalam upaya meningkatkan mutu pendidikan di sekolah.

\section{METODOLOGI PENELITIAN}

Rancangan penelitian ini adalah Penelitian Tindakan Kelas (PTK). Penelitian tindakan kelas ini dilakukan dalam 2 siklus dengan menggunakan model yang dikembangkan oleh Arikunto. Tiap siklus terdiri dari empat tahap kegiatan yaitu tahap perencanaan, pelaksanaan, pengamatan, dan refleksi. Variabel bebas dalam penelitian ini adalah Model pembelajaran cooperative tipe student teams achievement division (STAD) dan variabel terikat pada penelitian ini adalah hasil belajar. Hasil belajar yang dimaksud dalam penelitian ini adalah hasil belajar siswa pada mata pelajaran ilmu pengetahuan alam (IPA) yang ditunjukkan dengan nilai dari pretest dan posttes yang diberikan guru kepada siswa setiap akhir siklus, setelah mengikuti proses pembelajaran dengan model pembelajaran cooperative tipe student teams achievement division (STAD).

Subjek Penelitian

Penelitian ini dilakukan di SD Negeri 1 Sidokerto Kecamatan Bumiratu Nuban dengan subjek tindakan siswa kelas
VB dengan jumlah siswa sebanyak 32 orang.

Teknik dan Instrumen Pengumpulan Data

Teknik pengumpulan data yang digunakan dalam penelitian ini adalah observasi, wawancara, dan tes. Instrumen data berupa pedoman wawancara, lembar observasi aktivitas siswa, dan soal tes.Uji Kemantapan Instrumen dilakukan dengan uji validitas dan reliabilitas butir soal.

Teknik Analisis Data

Metode analisis data pada penelitian ini digunakan dengan menggunakan analisis kualitatif dan analisis kuantitatif. Analisis kuantitatif dilakukan untuk menguji hasil posttest yang diperoleh siswa. Selain itu, nilai posttest dianalisis dengan perhitungan Skor Gain (gain-score) ternormalisasi. Skor Gain ini dihitung dengan rumus yang dikembangkan oleh Hake sebagai berikut:

N-Gain $=\quad \frac{\text { Spost- Spre }}{\text { Smaks-Spre }}$

Dengan kriteria nilai N-gain:

Tabel 2. Daftar kriteria nilai N-Gain

\begin{tabular}{|l|l|}
\hline Perolehan N-Gain & Kriteria \\
\hline N-Gain $>0,70$ & Tinggi \\
\hline $0,30 \leq \mathrm{N}$-gain $\leq 0,70$ & Sedang \\
\hline $\mathrm{N}$ - Gain $<0,30$ & Rendah \\
\hline
\end{tabular}

Analisis kualitatif dilakukan untuk mengetahui aktivitas siswa dan guru selama proses pembelajaran dengan menggunakan model pembelajaran cooperative tipe student teams achievement division (STAD).

\section{HASIL PENELITIAN DAN PEMBAHASAN}

Penelitian Tindakan Kelas (PTK) ini bertujuan untuk meningkatkan hasil belajar IPA siswa kelas VB SD Negeri 1 Sidokerto Kecamatan Bumiratu Nuban dengan menggunakan model pembelajaran cooperative tipe student teams achievement division (STAD). Penelitian ini dilaksanakan dalam 2 siklus dengan setiap 
siklus terdiri dari 3 kali pertemuan. Secara garis besar proses tahapan pelaksanaan pada siklus I adalah perencanaan, pelaksanaan, observasi dan refleksi.

\section{Perencanaan}

Pada tahap ini kegiatan yang dilakukan peneliti meliputi: pembuatan rencana pelaksanaan pembelajaran (RPP), mempersiapkan alat evaluasi, merancang alat pengumpul data, mempersiapkan lembar kegiatan siswa (LKS) dan membagi siswa dalam kelompok heterogen.

Pelaksanaan

Tahap ini merupakan tahap penerapan dari kegiatan pembelajaran yang telah disusun dalam perencanaan yaitu melaksanakan kegiatan pembelajaran dengan menggunakan model cooperative tipe student teams achievement division (STAD). Pada siklus I dilaksanakan sebanyak $3 x$ pertemuan.

\section{Observasi / Pengamatan}

Pada tahap ini dilakukan pengamatan atau observasi terhadap kinerja guru dan aktivitas siswa oleh observer dengan menggunakan lembar observasi yang telah disiapkan.

Hasil observasi aktivitas siswa

Aktivitas siswa merupakan segala sesuatu yang dilakukan siswa selama proses pembelajaran berlangsung. Dalam Penelitian ini terdapat 4 indikator penilaian dari aktivitas siswa. Adapaun indikator yang diamati yaitu; siswa memperhatikan penjelasan guru, memberikan pendapat dalam diskusi, kerja sama dalam diskusi, dan menyelesaikan tugas yang diberikan guru. Berikut ini adalah rekapitulasi data aktivitas siswa siklus I.

Tabel 3. Presentase Aktivitas Belajar Siklus I

\begin{tabular}{|l|l|l|l|l|}
\hline Aktivitas Yang & \multicolumn{2}{|l|}{ Pertemuan } & Rata- \\
\cline { 2 - 4 } Diamati & 1 & 2 & 3 & rata \\
\hline $\begin{array}{l}\text { Siswa } \\
\text { memperhatikan } \\
\text { penjelasan guru }\end{array}$ & $69 \%$ & $72 \%$ & $78 \%$ & \\
\hline
\end{tabular}

\begin{tabular}{|l|l|l|l|l|}
\hline $\begin{array}{l}\text { Memberikan } \\
\text { pendapat dalam } \\
\text { diskusi }\end{array}$ & $72 \%$ & $78 \%$ & $81 \%$ & $77 \%$ \\
\hline $\begin{array}{l}\text { Kerja sama } \\
\text { dalam diskusi }\end{array}$ & $78 \%$ & $84 \%$ & $78 \%$ & $80 \%$ \\
\hline $\begin{array}{l}\text { Menyelesaikan } \\
\text { tugas yang } \\
\text { diberikan guru }\end{array}$ & $78 \%$ & $72 \%$ & $84 \%$ & $78 \%$ \\
\hline Jumlah & 74,25 & 76,5 & 80,25 & $77 \%$ \\
\hline
\end{tabular}

Berdasarkan tabel di atas dapat dilihat aktivitas siswa dalam memperhatikan penjelasan guru pada pertemuan I yaitu $69 \%$, pertemuan II $72 \%$ dan pertemuan III $78 \%$ dengan rata-rata $73 \%$. Aktivitas kedua yaitu memberikan pendapat dalam diskusi pada pertemuan pertama yaitu $72 \%$ pertemuan kedua $78 \%$ dan pertemuan ketiga $81 \%$ dengan rata-rata $77 \%$. Aktivitas ketiga yaitu kerja sama dalam diskusi pada pertemuan pertama $78 \%$, pertemuan kedua $84 \%$ dan pertemuan ketiga $78 \%$ dengan rata-rata $80 \%$. Aktivitas keempat yaitu menyelesaikan tugas yang diberikan guru pada pertemuan pertama sebesar $78 \%$, pertemuan kedua $72 \%$ dan pertemuan ketiga $84 \%$ dengan rata-rata $78 \%$.

Dari keempat aktivitas tersebut yang telah mencapai target ketuntasan adalah kerja sama dalam diskusi, karena masing-masing aktivitas tersebut telah mencapai target yang direncanakan. Untuk akivitas yang lainnya tidak mencapai target yang ditentukan, atau dapat dikatakan tidak tuntas.

\section{Hasil observasi kinerja guru.}

Dalam proses pembelajaran dengan menggunakan model pembelajaran cooperative tipe student teams achievement division (STAD)kinerja guru diamati dalam lembar observasi kinerja guru yang telah dibuat oleh peneliti. Observasi kinerja guru meliputi 12 indikator penilaian. Dari pengamatan kinerja guru pada siklus pertama mengalami peningkatan dari pertemuan satu sampai pertemuan ketiga. Skor tertinggi pada indikator penguasaan model pembelajaran cooperative tipe student teams achievement division (STAD) dan kemampuan menggunakan 
alat/media dengan rata-rata 76 dan terendah penguasaan kelas dengan rata-rata 69,33.

\section{Hasil Belajar Siklus I}

Hasil belajar yang dimaksud yaitu hasil belajar siswa pada mata pelajaran ilmu pengetahuan alam (IPA) yang ditunjukkan dengan nilai dari pretest dan posttest setiap akhir siklus setelah mengikuti proses pembelajaran dengan model pembelajaran cooperative tipe student teams achievement division (STAD).Berikut ini adalah rekapitulasi data hasil belajar siswa pada siklus I.

Tabel 4. Hasil belajar siswa siklus

\begin{tabular}{|c|c|c|c|c|}
\hline \multirow{2}{*}{ Indikator } & \multicolumn{3}{|c|}{ 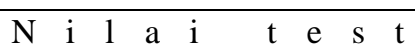 } & \multirow{2}{*}{ Kriteria } \\
\hline & Pretest & Posttest & $\mathrm{N}$-Gain & \\
\hline Rata-rata & $57,81 \%$ & $67,65 \%$ & 0,33 & Sedang \\
\hline Skor tertinggi & 9 & $\begin{array}{lll}1 & 0 & 0\end{array}$ & & \\
\hline Skor terendah & 3 & 4 & & \\
\hline Tingkat ketuntasan & $53,13 \%$ & $62,5 \%$ & & \\
\hline
\end{tabular}

Berdasarkan tabel di atas terlihat bahwa setelah pelaksanaan pembelajaran pada siklus 1 yang terbagi menjadi 3 kali pertemuan, siswa yang tuntas berjumlah $62,5 \%$ pada posttest dengan peningkatan rata-rata $\mathrm{N}$-gain 0,33 kriteria sedang.

Dari hasil posstest dapat dihitung skor kemajuan siswa. Dari point kemajuan siswa, dapat diketahui kelompok mana yang memperoleh point tertinggi. Kelompok dengan point tertinggi diberikan penghargaan atas kinerja kelompok tersebut. Berikut data kelompok dengan point tertinggi.

Tabel 5. Kelompok dengan point tertinggi

\begin{tabular}{|c|c|c|c|c|c|}
\hline $\mathrm{Kel}$ & Nama & Pretest & Posttest & Point & $\begin{array}{l}\text { Kriteria } \\
\text { pengha } \\
\text { rgaan }\end{array}$ \\
\hline \multirow{5}{*}{4} & $\mathrm{Dmn}$ & 5 & 7 & \multirow{5}{*}{24} & \multirow{5}{*}{$\begin{array}{l}\text { Tim } \\
\text { Hebat }\end{array}$} \\
\hline & $\begin{array}{ll}S & 1\end{array}$ & 5 & 5 & & \\
\hline & Y k & 5 & 7 & & \\
\hline & E y & 4 & 5 & & \\
\hline & $\mathrm{Zm}$ & 6 & 7 & & \\
\hline
\end{tabular}

Berdasarkan data pada tabel tersebut, kelompok 4 merupakan kelompok dengan point tertinggi yaitu 24 , kelompok 4 terdiri dari 5 siswa dan mendapatkan predikat tim hebat.

Penghargaan tersebut diberikan sebagai salah satu ciri dari cooperative tipe student teams achievement division (STAD) dan sebagai pendorong motivasi siswa maupun kelompok untuk belajar. Masing-masing siswa berupaya mendapatkan point terbaik sehingga mendapatkan penghargaan.

Refleksi

Dari hasil observasi pembelajaran pada siklus I, refleksi yang diperoleh antara lain: beberapa siswa tidak memperhatikan penjelasan guru, terdapat beberapa siswa yang masih belum memberikan pendapat dan tidak mau bekerja sama dalam diskuasai, masih ada beberapa siswa yang kurang mengoptimalkan ketepatan dan keefisienan waktu yang tersedia terhadap tugas yang diberikan guru, dan hasil belajar siswa yang tuntas sebanyak sebanyak 20 siswa atau $62,5 \%$. Sedangkan yang belum tuntas sebanyak 12 siswa atau $37,5 \%$. Sehingga dapat di ketahui bahwa hasil belajar siswa belum mencapai target yang direncanakan yaitu KKM 60 mencapai $\geq 75 \%$.

Setelah diadakan refleksi dan hasil yang diperoleh pada siklus I belum mencapai target yang direncanakan maka dilaksanakan siklus II. Adapun tahapan pada siklus II sama dengan siklus I yaitu terdiri dari perencanaan, pelaksanaan, observasi, dan refleksi.

\section{Perencanaan}

Perencanaan tindakan kelas yang dilakukan pada sikus II ini berdasarkan pada siklus I, Tahapan pada siklus II masih sama pada siklus I.

Pelaksanaan

Pelaksanaan yang dilakukan pada siklus II untuk memperbaiki proses pembelajaran pada siklus I. 
Observasi

Pada tahap ini dilakukan pengamatan atau observasi terhadap kinerja guru dan aktivitas siswa oleh observer dengan menggunakan lembar observasi yang telah disiapkan. Berikut ini adalah hasil observasi yang dilakukan oleh observer.

\section{Hasil observasi aktivitas Siswa}

Aktivitas yang diamati pada siklus II sama dengan indikator yang terdapat pada instrument pada siklus I. Adapaun indikator yang diamati yaitu; siswa memperhatikan penjelasan guru, memberikan pendapat dalam diskusi, kerja sama dalam diskusi, dan enyelesaikan tugas yang diberikan guru. Berikut ini adalah rekapitulasi data aktivitas siswa siklus II.

Tabel 6. Presentase Aktivitas Belajar Siklus II

\begin{tabular}{|l|l|l|l|l|}
\hline Aktivitas Yang & \multicolumn{2}{|l|}{ Pertemuan } & Rata- \\
\cline { 2 - 5 } Diamati & 1 & 2 & 3 & rata \\
\hline $\begin{array}{l}\text { Siswa } \\
\text { memperhatikan } \\
\text { penjelasan guru }\end{array}$ & $75 \%$ & $78 \%$ & $87 \%$ & $80 \%$ \\
\hline $\begin{array}{l}\text { Memberikan } \\
\text { pendapat dalam } \\
\text { diskusi }\end{array}$ & $87 \%$ & $87 \%$ & $87 \%$ & $87 \%$ \\
\hline $\begin{array}{l}\text { Kerja sama } \\
\text { dalam diskusi }\end{array}$ & $78 \%$ & $84 \%$ & $87 \%$ & $83 \%$ \\
\hline $\begin{array}{l}\text { Menyelesaikan } \\
\text { tugas yang } \\
\text { diberikan guru }\end{array}$ & $91 \%$ & $91 \%$ & $94 \%$ & $92 \%$ \\
\hline Jumlah & 82,75 & 85 & 88,75 & 85,5 \\
\hline
\end{tabular}

Berdasarkan tabel di atas dapat dilihat aktivitas siswa dalam memperhatikan penjelasan guru pada pertemuan I yaitu $75 \%$, pertemuan II $78 \%$ dan pertemuan III $87 \%$ dengan rata-rata $80 \%$. Aktivitas kedua yaitu memberikan pendapat dalam diskusi pada pertemuan pertama yaitu $87 \%$ pertemuan kedua $87 \%$ dan pertemuan ketiga $87 \%$ dengan rata-rata $87 \%$. Aktivitas ketiga yaitu kerja sama dalam diskusi pada pertemuan pertama $78 \%$, pertemuan kedua $84 \%$ dan pertemuan ketiga $87 \%$ dengan rata-rata $83 \%$. Aktivitas keempat yaitu menyelesaikan tugas yang diberikan guru pada pertemuan pertama sebesar $91 \%$, pertemuan kedua $91 \%$ dan pertemuan ketiga 94\% dengan rata-rata $92 \%$.

Dari keempat aktivitas tersebut terlihat bahwa aktivitas belajar siswa pada siklus II mengalami peningkatan dari pertemuan satu sampai dengan pertemuan ketiga. Dan dapat dikatakan dari keempat aktivitas tersebut telah mencapai target ketuntasan yang telah ditetapkan.

Hasil observasi kinerja guru.

Kinerja guru pada siklus II mengalami peningkatan dari pertemuan satu sampai pertemuan ketiga. Pada siklus II terjadi pula peningkatan dari masingmasing indikator. skor tertinggi terdapat pada indikator kemampuan mengguanakan alat/media dengan rata-rata 81,67 dan indikator terendah pada penguasaan kelas dengan rata-rata 74 .

Hasil Belajar Siklus II

Hasil belajar berupa nilai dari pretest dan posttestdiakhir siklus setelah mengikuti proses pembelajaran dengan model pembelajaran cooperative tipe student teams achievement division (STAD). Berikut ini adalah rekapitulasi data hasil belajar siswa pada siklus II.

Tabel 7. Hasil belajar siswa siklus II

\begin{tabular}{|c|c|c|c|c|c|}
\hline \multirow{2}{*}{ Indikator } & $\mathrm{N} \quad \mathrm{i} \quad \mathrm{l}$ & $\begin{array}{ll}\mathrm{a} & \mathrm{i} \\
\end{array}$ & $\mathrm{t}$ & $\begin{array}{lll} & \mathrm{s} & \mathrm{t} \\
\end{array}$ & \multirow{2}{*}{ Kriteria } \\
\hline & Pretest & \multicolumn{2}{|c|}{ Posttest } & N-Gain & \\
\hline Rata-rata & $65 \%$ & 79,53 & & 0,58 & Sedang \\
\hline Skor tertinggi & 9 & 10 & 0 & & \\
\hline Skor terendah & 4 & 5 & 5 & & \\
\hline Tingkat ketuntasan & $68,75 \%$ & 90,63 & & & \\
\hline
\end{tabular}

Tabel di atas menunjukkan data hasil belajar siswa pada siklus II, pada awal tes (pretest) hanya mencapai $68,75 \%$ dan pada akhir siklus (posttest) dapat mencapai $90,63 \%$ dengan peningkatan rata-rata $\mathrm{N}$ Gain 0,58 kriteria sedang. Pada siklus II hasil belajar siswa sudah mencapai target dan mengalami peningkatan hasil belajar. Hasil yang diperoleh dapat memenuhi 
indikator keberhasilanmencapai $>75 \%$ pada akhir siklus.

Dari hasil posstest siklus II dihitung skor kemajuan siswa. Dari skor kemajuan siswa, dapat diamati kelompok yang memperoleh point tertinggi. Apakah kelompok pada siklus I atau kelompok lain. Kelompok dengan point tertinggi diberikan penghargaan atas kinerja kelompok tersebut. Berikut ini data kelompok dengan point tertinggi.

Tabel 8. Kelompok dengan point tertinggi

\begin{tabular}{|c|c|c|c|c|c|c|c|c|}
\hline Kel & Nama & \multicolumn{2}{|c|}{ Pretest } & \multicolumn{2}{|c|}{ Posttest } & \multicolumn{2}{|c|}{ Point } & Kriteria penghargaan \\
\hline \multirow{4}{*}{7} & $\mathrm{D}$ i s & 5 & 0 & 7 & 0 & & \multirow{4}{*}{0} & \multirow{4}{*}{ Tim Super } \\
\hline & $\mathrm{S} \mathrm{j} \mathrm{p}$ & 7 & 0 & 8 & 5 & & & \\
\hline & A $1 \mathrm{~s}$ & 5 & 0 & 7 & 0 & & & \\
\hline & $\mathrm{D}$ a p & 5 & 5 & 7 & 0 & & & \\
\hline
\end{tabular}

Berdasarkan data pada tabel di atas, kelompok 7 merupakan kelompok dengan point tertinggi yaitu 24, kelompok 7 terdiri dari 4 siswa dan mendapatkan predikat tim Super.

Refleksi

Dari hasil yang diperoleh pada siklus II, dapat disimpulkan bahwa penggunaan model pembelajaran Cooperative tipe Student Teams Achievement Division (STAD) dapat meningkatkan aktivitas dan hasil belajar siswa. Pada siklus II siswa lebih mengerti tentang pentingnya bekerja sama dalam kelompok untuk menyelesaikan tugas, guru dapat menggunakan model pembelajaran Cooperative tipe Student Teams Achievement Division (STAD) untuk membantu meningkatkan aktivitas dan hasil belajar siswa.

\section{Pembahasan}

\section{Aktivitas Belajar Siswa}

Terdapat peningkatan altivitas siswa pada siklus I dan siklus II. Berikut ini tabel peningkatan aktivitas siswa yang terjadi dari siklus I dan II.
Tabel 9. Data Rata-Rata Aktivitas Belajar Siswa Pada Siklus I dan Siklus II

\begin{tabular}{|l|l|l|l|}
\hline $\begin{array}{l}\text { Aktivitas Yang } \\
\text { Diamati }\end{array}$ & $\begin{array}{l}\text { Siklus } \\
\text { I }\end{array}$ & $\begin{array}{l}\text { Siklus } \\
\text { II }\end{array}$ & Peningkatan \\
\hline $\begin{array}{l}\text { Siswa } \\
\text { memperhatikan } \\
\text { penjelasan } \\
\text { guru }\end{array}$ & $73 \%$ & $80 \%$ & $7 \%$ \\
\hline $\begin{array}{l}\text { Memberikan } \\
\text { pendapat } \\
\text { dalam diskusi }\end{array}$ & $77 \%$ & $87 \%$ & $10 \%$ \\
\hline $\begin{array}{l}\text { Kerja sama } \\
\text { dalam diskusi }\end{array}$ & $80 \%$ & $83 \%$ & $3 \%$ \\
\hline $\begin{array}{l}\text { Menyelesaikan } \\
\text { tugas yang } \\
\text { diberikan guru }\end{array}$ & $78 \%$ & $92 \%$ & $14 \%$ \\
\hline Jumlah & $308 \%$ & $342 \%$ & $34 \%$ \\
\hline Rata-Rata & $77 \%$ & $85,5 \%$ & $8,5 \%$ \\
\hline
\end{tabular}

peningkatan. Peningkatan dengan skor terbesar yaitu pada indikator menyelesaikan tugas yang diberikan guru, mencapai $14 \%$.

\section{Kinerja guru}

Berdasarkan hasil penelitian, penilaian kinerja guru dengan menggunakan model pembelajaran cooperative tipe student teams achievement division (STAD) mengalami peningkatan pada setiap siklusnya. Peningkatan kinerja guru dalam pembelajaran tersebut dapat dilihat pada tabeldi bawah ini:

Tabel 10. Data Rata-rata dan peningkatan Aktivitas Guru Siklus I dan Siklus II

\begin{tabular}{|l|l|l|l|}
\hline $\begin{array}{l}\text { Aktivitas yang } \\
\text { diamati }\end{array}$ & $\begin{array}{l}\text { Siklus } \\
\text { I }\end{array}$ & $\begin{array}{l}\text { Siklus } \\
\text { II }\end{array}$ & $\begin{array}{l}\text { Peningka } \\
\text { tan }\end{array}$ \\
\hline $\begin{array}{l}\text { Keterampilan } \\
\text { membuka } \\
\text { pelajaran }\end{array}$ & 72 & 76,67 & 4,67 \\
\hline $\begin{array}{l}\text { Kemampuan } \\
\text { guru } \\
\text { mengorganisasik } \\
\text { an siswa dalam } \\
\text { kelompok belajar }\end{array}$ & 73,33 & 78,67 & 5,34 \\
\hline $\begin{array}{l}\text { Kemampuan } \\
\text { guru memantau } \\
\text { jalannya diskusi } \\
\text { siswa }\end{array}$ & 74,33 & 79 & 4,67 \\
\hline $\begin{array}{l}\text { Penguasaan } \\
\text { bahan pelajaran }\end{array}$ & 75,33 & 80,67 & 5,34 \\
\hline $\begin{array}{l}\text { Penguasaan } \\
\text { penggunaan } \\
\text { model }\end{array}$ & 76 & 81 & 5 \\
\hline
\end{tabular}




\begin{tabular}{|l|l|l|l|}
\hline $\begin{array}{l}\text { Keterampilan } \\
\text { menjelaskan }\end{array}$ & 74 & 79,33 & 5,33 \\
\hline $\begin{array}{l}\text { Penguasaan } \\
\text { kelas }\end{array}$ & 69,33 & 74 & 4,67 \\
\hline $\begin{array}{l}\text { Kemampuan } \\
\text { menggunakan } \\
\text { alat/media }\end{array}$ & 76 & 81,67 & 5,67 \\
\hline $\begin{array}{l}\text { Kemampuan } \\
\text { berkomunikasi } \\
\text { dalam PBM } \\
\text { yang } \\
\text { komunikatif }\end{array}$ & 72,33 & 75,67 & 3 \\
\hline $\begin{array}{l}\text { Keterampilan } \\
\text { memberi } \\
\text { penguatan }\end{array}$ & 72,67 & 75,67 & 3 \\
\hline $\begin{array}{l}\text { Kemampuan } \\
\text { mengevaluasi }\end{array}$ & 74 & 78,33 & 4,33 \\
\hline $\begin{array}{l}\text { Kemampuan } \\
\text { menutup } \\
\text { pelajaran }\end{array}$ & 72,33 & 76,67 & 4,34 \\
\hline Jumlah & 881,65 & 937,35 & 55,36 \\
\hline Rata-rata & 73,47 & 78,11 & 59,97 \\
\hline
\end{tabular}

Berdasarkan data hasil Penelitian,

kinerja guru mengalami peningkatan dari siklus I dan siklus II. Peningkatan terjadi dari masing-masing indikator penilaian. Skor terbesar pada indikator kemampuan guru memantau jalannya diskusi siswa dan Keterampilan menjelaskan, yaitu mencapai 5,33 .

Tabel 11. Rata-Rata Hasil Belajar Siswa

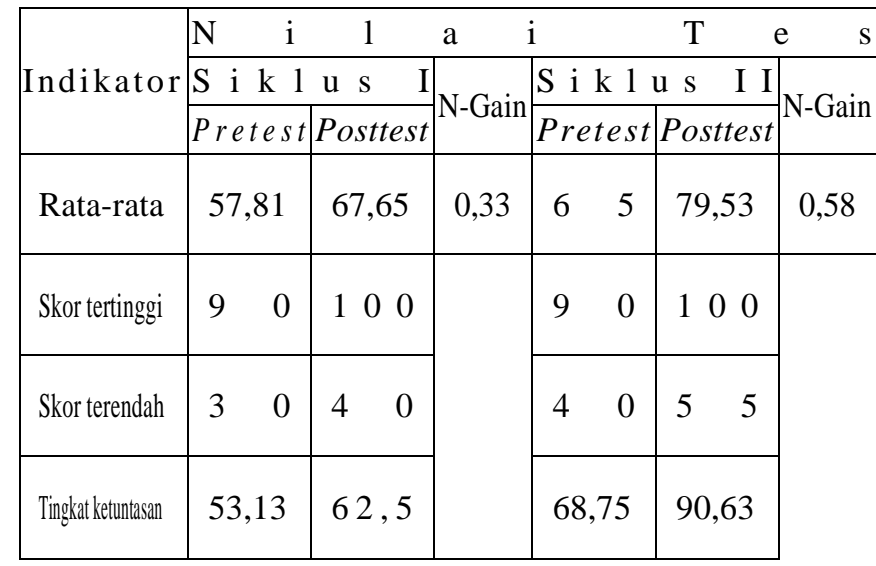

Untuk lebih jelasnya peningkatan hasil belajar siswa dalam pembelajaran IPA dengan penggunaan model pembelajaran cooperative tipe student teams achievement division (STAD) kelas VB SD Negeri 1 Sidokerto dapat dilihat pada gambar berikut:

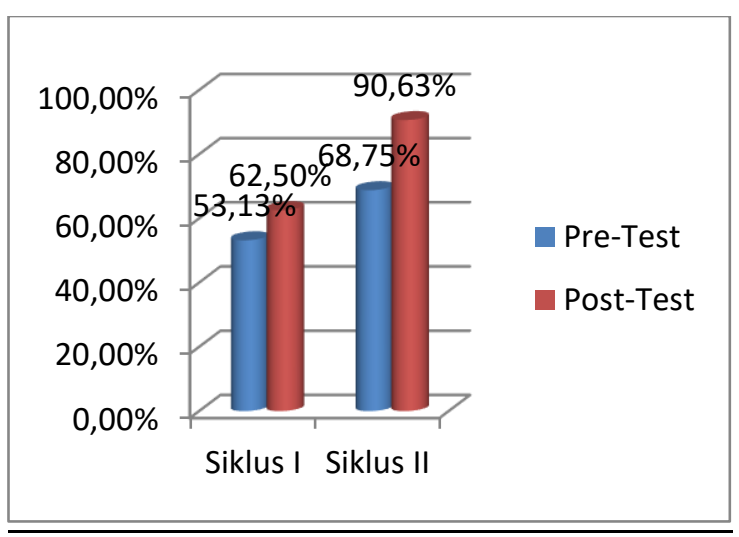

Grafik 1. Tingkat Ketuntasan Hasil Belajar Siswa Siklus I dan Siklus II

Berdasarkan tabel dan gambar tersebut tingkat ketuntasan hasil belajar pada siklus I untuk pretest $53,13 \%$ dan posttest $62,5 \%$ dengan rata-rata $\mathrm{N}$-Gain siklus I 0,33 sedangkan pada siklus II tingkat ketuntasan hasil belajar untuk pretest sebesar $68,75 \%$, dan posttest sebesar 90,63\% dengan ratarata $\mathrm{N}$-Gain 0,58 . Jadi tingkat ketuntasan hasil belajar siklus I $62,5 \%$ dan siklus II $90,63 \%$, maka telah tercapai ketuntasan belajar lebih dari $75 \%$ pada akhir siklus.

Adapun peningkatan N-Gain pada siklus I dan siklus II dalam pembelajaran IPA dengan menggunakan model pembelajaran cooperative tipe student teams achievement division (STAD) kelas VB SD Negeri 1 Sidokerto dapat dilihat pada gambar berikut:

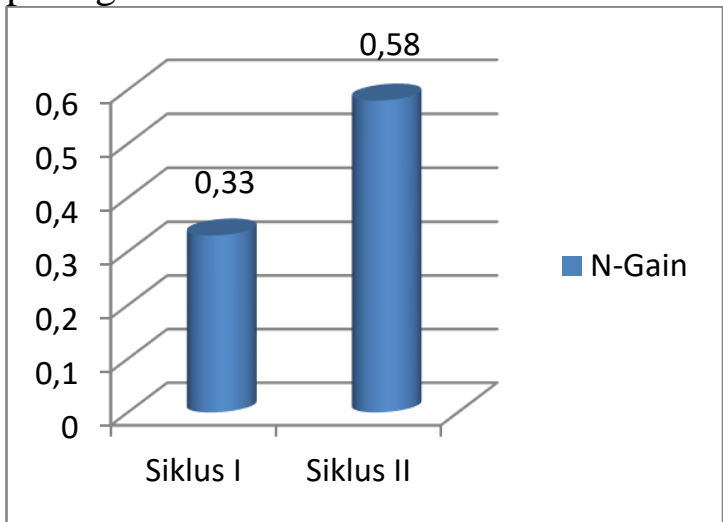

Grafik 2. Peningkatan N-Gain dari Hasil Belajar Sisklus I dan Siklus II

Berdasarkan gambar di atas, pada siklus I diperoleh $\mathrm{N}$-Gain 0,33 dan pada siklus II diperoleh $\mathrm{N}$-Gain 0,58. Sehingga terjadi peningkatan sebesar 0,25 dari siklus I ke siklus II. Peningkatan ini terjadi karena ketelaksanaan pembelajaran pada siklus II 
lebih baik jika dibandingkan dengan siklus I.

Meningkatnya hasil belajar siswa dari siklus I ke siklus II disebabkan karena prosedur yang ada dalam model pembelajaran cooperative tipe student teams achievement division (STAD), dimana dalam setiap kelompok terdapat siswa yang memiliki kemampuan akademik lebih tinggi dan dapat dijadikan tutor bagi teman sekelompoknya sehingga ketika siswa mengalami kesulitan dalam memahami materi maka ia mempunyai kesempatan untuk menanyakan kepada temannya, dan temannya akan memberikan bantuan kepadanya dengan menjelasakan kepada anggotanya yang lain sampai mengerti.

Pernyataan tersebut sesuai dengan pernyataan bahwa pembelajaran cooperative tipe student teams achievement division (STAD) merupakan model pembelajaran yang mengelompokkan siswa secara heterogen, kemudian siswa yang pandai menjelaskan pada anggota lain sampai mengerti. Sehingga pada saat siswa mengerjakan soal yang diberikan guru siswa dapat mengerjakan dengan baik dan benar. Dengan lebih banyaknya siswa beraktivitas yang sesuai dengan model pembelajaran yang digunakan maka akan berdampak pada hasil belajar siswa.

Dari pembahasan di atas dapat disimpulkan bahwa penggunaan model pembelajaran cooperative tipe student teams achievement division (STAD)dapat meningkatkan aktivitas dan hasil belajar siswa pada mata pelajaran ilmu pengetahuan alam kelas VB.

\section{KESIMPULAN}

Berdasarkan hasil penelitian, maka dapat disimpulkan bahwa model pembelajaran cooperative tipe student teams achievement division (STAD) dapat meningkatkan aktivitas belajar siswa, dilihat dari rata-rata persentase aktivitas belajar siswa pada siklus I sebesar $77 \%$ dan siklus II $85,5 \%$. Hal ini mengalami peningkatan sebesar $8.5 \%$. Selanjutnya model pembelajaran cooperative tipe student teams achievement division (STAD) dapat meningkatkan ketuntasan hasil belajar Ilmu Pengetahuan Alam. Persentase ketuntasan hasil belajar pada siklus I sebesar 62,5\% dan siklus II sebesar 90,63\%, sehingga mengalami peningkatan sebesar $28,13 \%$. Sedangkan dilihat dari skor rata-rata NGain juga mengalami peningkatan. Dapat ditunjukkan dari gain score sebesar 0,33 pada siklus I menjadi 0,58 pada siklus II. Hal ini berarti mengalami peningkatan sebesar 0,25 dengan kategori gain score sedang.

Saran

Model pembelajaran Cooperative tipe Student Teams Achievement Division (STAD) dapat dijadikan alternatif dalam memberikan sumbangan pemikiran dan informasi khususnya bagi guru IPA guna meningkatkan aktivitas dan hasil belajar.

\section{DAFTAR PUSTAKA}

Dimyati dan Mudjiono, Belajar dan Pembelajaran, Jakarta: PT. Rineka Cipta, 2009.

Isjoni, Cooperative Learning, Cetakan 2, Bandung: Alfabeta, 2009.

Isjoni, Cooperative Learning, Cetakan 5, Bandung: Alfabeta, 2011.

Kokom Komalasari, Pembelajaran Kontekstual, Bandung: PT. Refika Aditama, 2009.

Roestiyah. 2001. Pembelajaran Cooperative tipe student teams achievement division (STAD) (Student Team Achievement Division). Tersedia padahttp:

//www.sarjanaku.com/2011/03/ pembelajaran-kooperatif-tipestad.html.Diakses pada 3 Juni 2012.

Suharsmi Arikunto, Penelitian Tindakan Kelas, Jakarta : PT. Bumi Aksara, 2008.

Suhendi, Pengembangan Kuliah Online Berbasis LMS, Metro: STAIN Jurai Siwo Metro, 2009. 